KATICA MILOŠ, Ph.D.

E-mail: katica.milos@fpz.hr

IVICA JURIĆ, M.Sc.

E-mail: jurici@fpz.hr

PERO ŠKORPUT, M.Sc.

E-mail: pero.skorput@fpz.hr

University of Zagreb,

Faculty of Transport and Traffic Sciences

Vukelićeva 4, HR-10000 Zagreb, Croatia
Science in Traffic and Transport Original Scientific Paper Accepted: May 20, 2010

Approved: Mar. 8, 2011

\title{
ALUMINIUM-BASED COMPOSITE MATERIALS IN CONSTRUCTION OF TRANSPORT MEANS
}

\section{ABSTRACT}

The implementation of the achievements in material science both through history as well as today, is directly indicated in the improvement of the efficiency of transport means which then results in the improvement of the technology of traffic and transport. Today's requirements in the area of engineering materials intended for the construction of transport means impose reduction of mass as one of the fundamental criterion.

Consideration of the technical and technological societies have been oriented towards light materials and the possibilities of their modification in order to substitute the past traditional heavy monoliths such as iron, steel, copper, etc. The potential has been recognised in the aluminium-based materials. Aluminium and its versions have been already widely used in automotive industry; however, their utility spectrum still avoids the tribologically sensitive purposes. This paper is focused on the possibility of producing such a material. Ceramic particles $\mathrm{Al}_{2} \mathrm{O}_{3}$ have been integrated into soft aluminium, various particle sizes and share, by powder metallurgy techniques. The mechanical properties of materials have been studied in dependence on the share, size of particles, type of $\mathrm{Al} / \mathrm{Al}_{2} \mathrm{O}_{3}$, as well as the graphite addition. $\mathrm{Al} / \mathrm{Al}_{2} \mathrm{O}_{3}$ composites have been produced without any problems and have shown satisfactory mechanical properties.

\section{KEYWORDS}

reduction of transport means mass, aluminium-based composites, $\mathrm{Al} / \mathrm{Al}_{2} \mathrm{O}_{3}$ composites

\section{INTRODUCTION}

The environmental and economic reasons as well as the need for improved designs in the manufacture of motor vehicles have imposed mass reduction as the fundamental criterion for their construction. These requirements include first of all the use of light materials which necessarily combines the knowledge of several engineering disciplines. Thus today, design, the science about materials and production interactively supplement each other trying to reduce the structural mass by considering not only the mass of all its single components but rather also the possibilities of improving their functionalities [1].

According to the theoretical considerations, vehicle mass reduction of $10 \%$ reduces the fuel consumption by about 5.5\% [2][14][15].

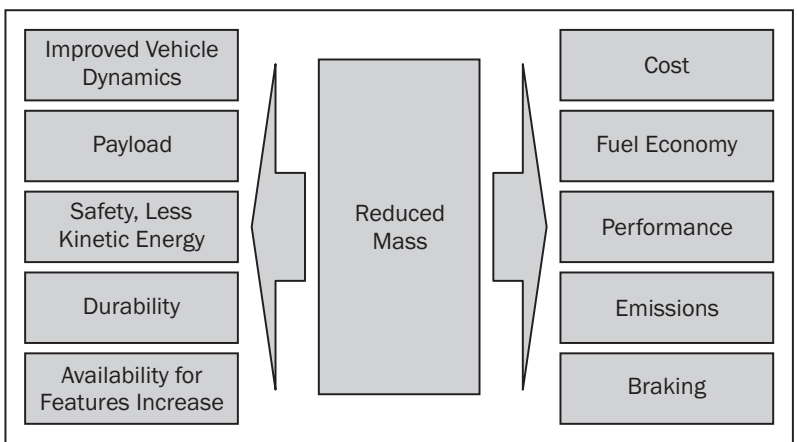

Figure 1 - Influence of weight reduction on properties and features [2][15]

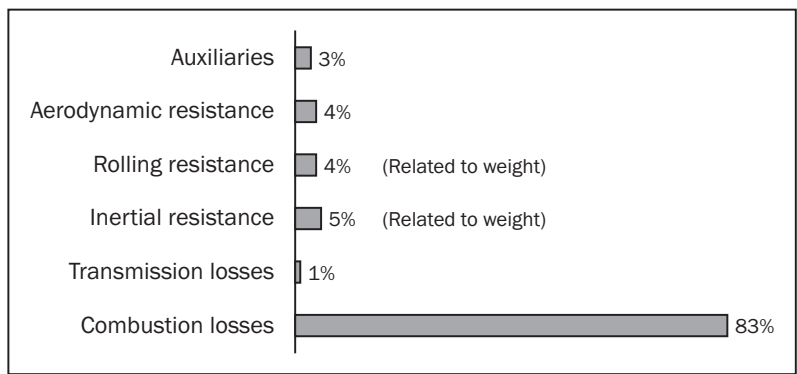

Figure 2 - Driving force for weight reduction - complete energy flow in EU combined (5-cyl-gasoline engine) [2][15]

The highest share in the total mass of vehicle are traditional heavy metals such as iron, steel and copper [2] [14] [19]. Light metals, polymers and their composite products in industrial practice are no unknowns and have already started to be used as substi- 
tute solutions. However, their share in the total mass reduction is significantly reduced by improving the vehicle design, transmission efficiency, safety-critical structures and comfort (anti-block systems, airbags, air-conditioning systems, etc.). Today's requirements for more radical interventions impose their more intensive development and implementation.

The developed production techniques, modelling simplicity and consequently low prices, make the heavy monoliths, especially steel and its versions still the most competitive materials [17] [18]. Light metals such as aluminium, magnesium and titan both because of the production price and because of the limitations by basic properties make it difficult to expand the usage spectrum [19].

These high requirements have brought the composite materials into the focus of present research. The potential of composite materials, as macroscopic combinations of dissimilar materials has been recognised in unlimited possibilities of moderation and combination of the desired properties of the constituents [1] [13].

Depending on the purpose of composites, one or several materials (hard phase), of different morphologies are integrated into the matrix material, forming thus very diverse spectrum of properties of hybrid products - composites, which regarding purpose exceed greatly the usage limits defined for the traffic means. The hard phase can be in several main forms: continuous and discontinuous fibres, needles or whiskers and spherical particles. The best mechanical properties of composites are achieved by using continuous fibres, and the worst by using particle forms. However, the non-isotropic properties of composites with continuous fibres due to complexity of production make them very expensive and mainly intended for high-value applications. The use of particles as hard phase is based on the isotropic properties of composites and the simplicity of the production process and consequently low price. From the technological aspect, after having selected the constituents, the basic aim in the production of composites is the achievement of good bonding of the matrix and the hard phase and homogeneous distribution of hard phase within the matrix [1] [14].

Unlike other light metals, aluminium with its characteristic properties such as high strength/density ratio, good corrosion resistance and thermal conductivity, machinability and recyclability and relatively low price, is one of the most prospective matrix metals for the production of composites. Today, in the construction of almost all traffic means, air, land, water, there is an entire series of developed aluminium alloys. Independent of the composition, production techniques and processing, all of them show very poor tribological properties. The possibility of integrating hard ceramic particles in the soft aluminium matrix promises great potential in this direction. The aluminium matrix provides ductility, and ceramics high strength and module of elasticity [1] [9] [10] [13]. Regarding ceramic materials as hard phase, most frequently $\mathrm{Al}_{2} \mathrm{O}_{3}$ and $\mathrm{SiC}$ are used. These composites are produced by liquid metallurgy and powder metallurgy. Principally in liquid metallurgy the hard phase particles are mixed into metal melt by various techniques, and in powder metallurgy the production of composites is carried out in several separate steps with the constituents being in hard state. The advantages of the liquid metallurgy techniques over those in powder metallurgy include good bonding of the matrix and the hard phase, simplicity of production, easier micro-structure control and lower composite price. The biggest problems are related to the impossibility of achieving homogeneous distribution of particles and integration of the major shares of the hard phase. The particle movement dynamics in the melt depends on the difference in the constituent density, so that the particles tend to orient themselves to the surface or to the melt bottom. High surface tension of aluminium is also cause of the difficulties with particle wetting.

On the contrary, the powder metallurgy techniques are not limited by the share, diversity of forms of the hard phase nor by the distribution. Great advantage lies also in the possibilities of producing complex shapes and the control of microstructure after each production step. The biggest drawback is the high price.

The improvement of tribological properties of aluminium-based materials, especially in the structures where there is possibility of lubricant collapse, would directly mean replacement of heavy monoliths, and then also the reduction of the total vehicle mass.

The topic of this paper is the development of $\mathrm{Al} /$ $\mathrm{Al}_{2} \mathrm{O}_{3}$ composite materials using the powder metallurgy techniques.

First of all, the possibility of integrating higher shares of hard ceramic phase $-\mathrm{Al}_{2} \mathrm{O}_{3}$ into pure aluminium is considered. The attention is focused on the share, distribution, size, form and type of $\mathrm{Al}_{2} \mathrm{O}_{3}$ particles and their influence on the mechanical properties of composites. Apart from this, $\mathrm{Al} / \mathrm{Al}_{2} \mathrm{O}_{3} /$ graphite composites have been prepared in order to analyze the influence of graphite on microstructure, mechanical properties and production of $\mathrm{Al} / \mathrm{Al}_{2} \mathrm{O}_{3}$ composites.

\section{EXPERIMENTAL PART}

\subsection{Characterization of initial materials - powders}

Materials used for the production of composites are powders of pure aluminium and aluminium oxides of the following characteristics:

- Powder of pure aluminium of high purity with average size of particle $<40 \mu \mathrm{m}$ (Ecka AS-011S), $\mathrm{O}_{2}$ 
content 0.3-0.4mas.\%, produced by air atomization by Ecka Granulate $\mathrm{GmbH}$, Velden, Germany.

- Two types of $\mathrm{Al}_{2} \mathrm{O}_{3}$ powder: Zwsk and Zesk (Treibacher Chemische Werke); Zwsk - white and practically pure $\mathrm{Al}_{2} \mathrm{O}_{3}$ with mean size of particle of 22 and $45 \mu \mathrm{m}$. Zesk - brown, content of $\mathrm{TiO}_{2}$ about $3.6 \mathrm{mas} \%$, with mean size of particle of 22.5 and $50 \mu \mathrm{m}$.

- Powder graphite, mean particle size $<75 \mu$ m (Elektrographit Lonza KS 75 quality).

Composition of composite compounds:

- $\mathrm{Al}+20,25,30,40$ and 50 mas $\% \mathrm{Al}_{2} \mathrm{O}_{3}$ Zesk 22.5 $\mu \mathrm{m}$

- $\mathrm{Al}+20,25,30,40$ and 50mas $\% \mathrm{Al}_{2} \mathrm{O}_{3}$ Zesk 50 $\mathrm{mm}$

- $\mathrm{Al}+20$ mas\% $\mathrm{Al}_{2} \mathrm{O}_{3}$ Zwsk $25 \mu \mathrm{m}$

- $\mathrm{Al}+20$ mas $\% \mathrm{Al}_{2} \mathrm{O}_{3}$ Zwsk $45 \mu \mathrm{m}$

- $\mathrm{Al}+25$ mas $\% \mathrm{Al}_{2} \mathrm{O}_{3}$ Zesk $22.5 \mu \mathrm{m}+2$ mas $\%$ graphite $75 \mu \mathrm{m}$

- $\mathrm{Al}+25$ mas $\% \mathrm{Al}_{2} \mathrm{O}_{3}$ Zesk $22.5 \mu \mathrm{m}+5$ mas $\%$ graphite $75 \mu \mathrm{m}$

- Al + 15mas\%graphite $75 \mu \mathrm{m}$

- Al + 20mas\%graphite $75 \mu \mathrm{m}$

\subsection{Production of composites}

All the composite compounds have been mixed in a mixer for $25 \mathrm{~min}$, and then compacted by being compressed under the pressure of 600MPa into rollers $60 \mathrm{~mm}$ in length and $40 \mathrm{~mm}$ in diameter (green compacts). The powder compound density $20-40 \%$, by compaction the density has been increased to $80-90 \%$ of the theoretical value. As press lubricant the $\mathrm{MoS}_{2}$ spray has been used.

The rollers were then wrapped into Al foil and heated to $500^{\circ} \mathrm{C}(60 \mathrm{~min})$ in extrusion pre-chambers. The $\mathrm{Al}$ foil has been used in order to reduce aluminium oxidation and to reduce friction during extrusion. The rollers have been extruded into bars of $10 \mathrm{~mm}$ in diameter. The extrudate surfaces were smooth, especially in case of samples with graphite content and lower $\mathrm{Al}_{2} \mathrm{O}_{3}$ contents.

Extrusion parameters

- Input roller temperature: $430^{\circ} \mathrm{C}$

- Temperature: $500^{\circ} \mathrm{C}$

- Ratio: 16:1

- Force: 800-1200 kN

- Speed: $10 \mathrm{~mm} / \mathrm{s}$

- Lubricant - graphite mass.

\subsection{Methods of analysis}

The microstructure has been analyzed by metallographic methods. The samples of extrudates have been taken parallel and vertical to the extrusion axis. For easier handling they have been partly laid into the synthetic resin. The surfaces of samples have been successively ground by $\mathrm{SiC}$ paper, of SiC particle gra- dation from $45 \mu \mathrm{m}$ to $15 \mu \mathrm{m}$, from rough towards fine. The samples have been ground under continuous water jet in order to minimize the plastic deformation of the surface, likely to occur because of the frictiongenerated heat.

The sample surfaces have been then polished by diamond paste $(7 \mu \mathrm{m}, 3 \mu \mathrm{m}$ and $1 \mu \mathrm{m})$ and analyzed by optical microscope. In order to obtain the best possible insight into the distribution of $\mathrm{Al}_{2} \mathrm{O}_{3}$ particles, the optical micrographs have been scanned and computer analyzed. As reference value the average projected surface of particles has been taken. The projected particle surfaces have been then grouped into classes, and then the distribution of surfaces of particle agglomerate within the particle classes has been determined.

The samples for measuring mechanical properties have been taken parallel to the direction of extrusion, machined into the standard form (6x30, DIN 50 125) then tested on the standard machine Zwick 1474 at a speed of $3 \mathrm{~mm} / \mathrm{min}$.

\section{RESULTS AND ANALYSIS}

\subsection{Microstructure}

Figures 3-6 show the microstructure of the selected samples. In low $\mathrm{Al}_{2} \mathrm{O}_{3}$ contents the uniform distribution of particles is visible. In case of high contents, strong agglomerates are clearly indicated regardless of the size of particles.

\subsection{Hardness}

The hardness of composite material is directly proportional to the quantity of integrated hard particles. According to theoretical assumptions the solidification and hardening of the matrix is a consequence of reduced movement of dislocations due to the presence of hard non-deformable particles during plastic deformation. With the equal quantity of hard phase, the hardness of composite should be lower in the composites with larger particles due to the greater distance between the particles. The obtained results confirm this: hardness declines with the growing share of larger particles.

\subsection{Tensile strength - Young's modulus of elasticity}

In ideal circumstances, where it is assumed that the particles of hard phase are well bonded to the matrix, homogeneously distributed and of uniform shape and size, tensile strength of composite should amount to somewhat more than the strength of pure matrix. 


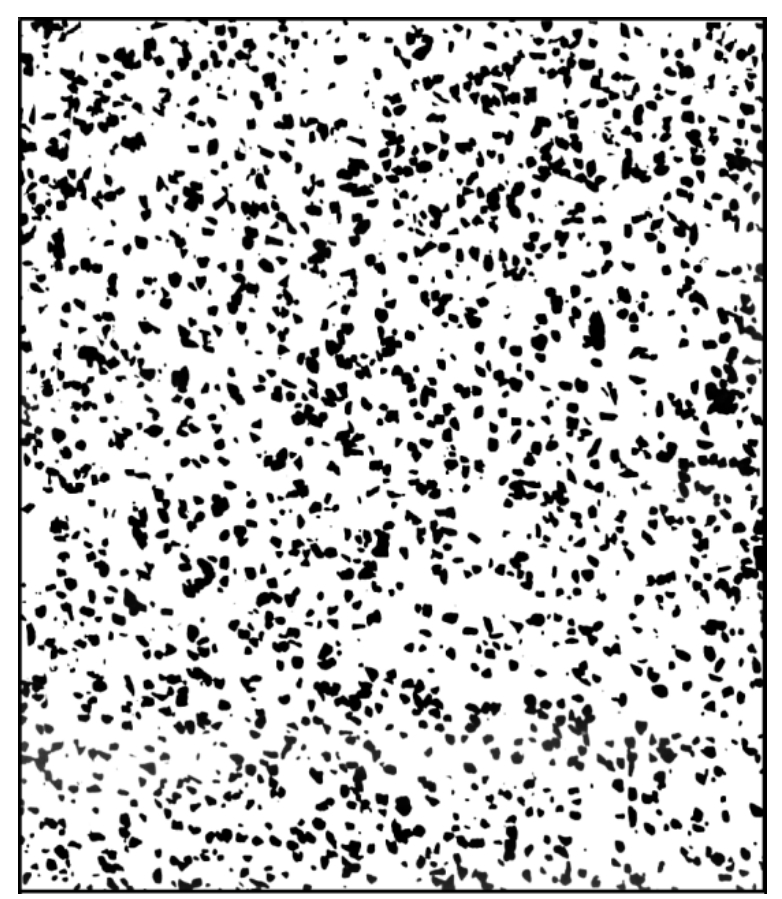

$\longmapsto 200 \mu \mathrm{m}$

Figure 3 - $\mathrm{Al}+20 \mathrm{wt} \% \mathrm{Al}_{2} \mathrm{O}_{3}(22.5 \mu \mathrm{m})$

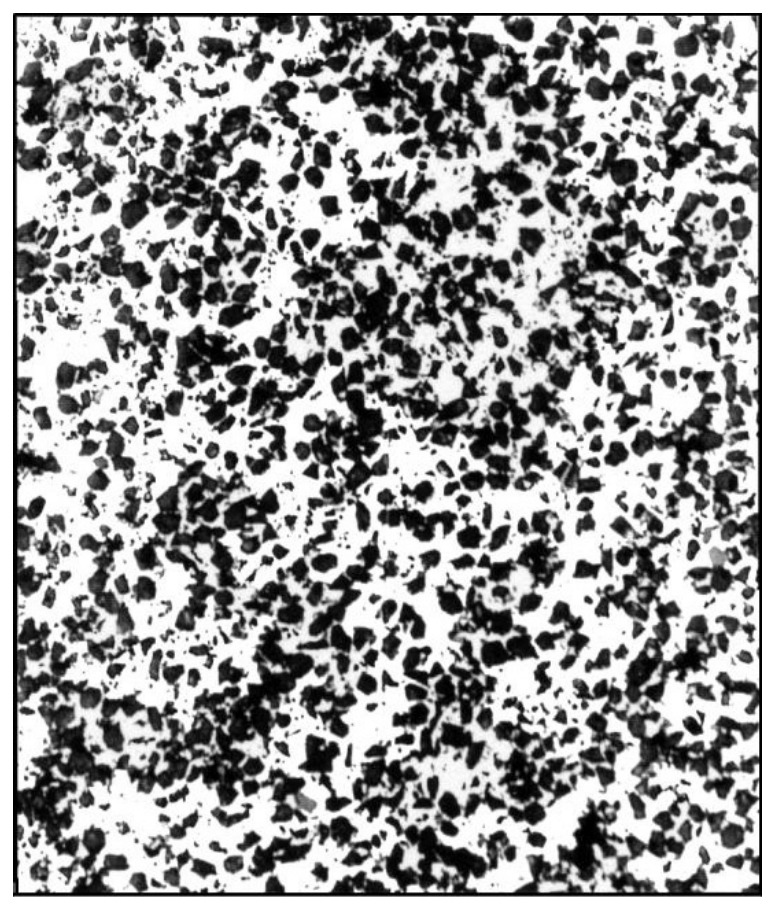

$100 \mu \mathrm{m}$

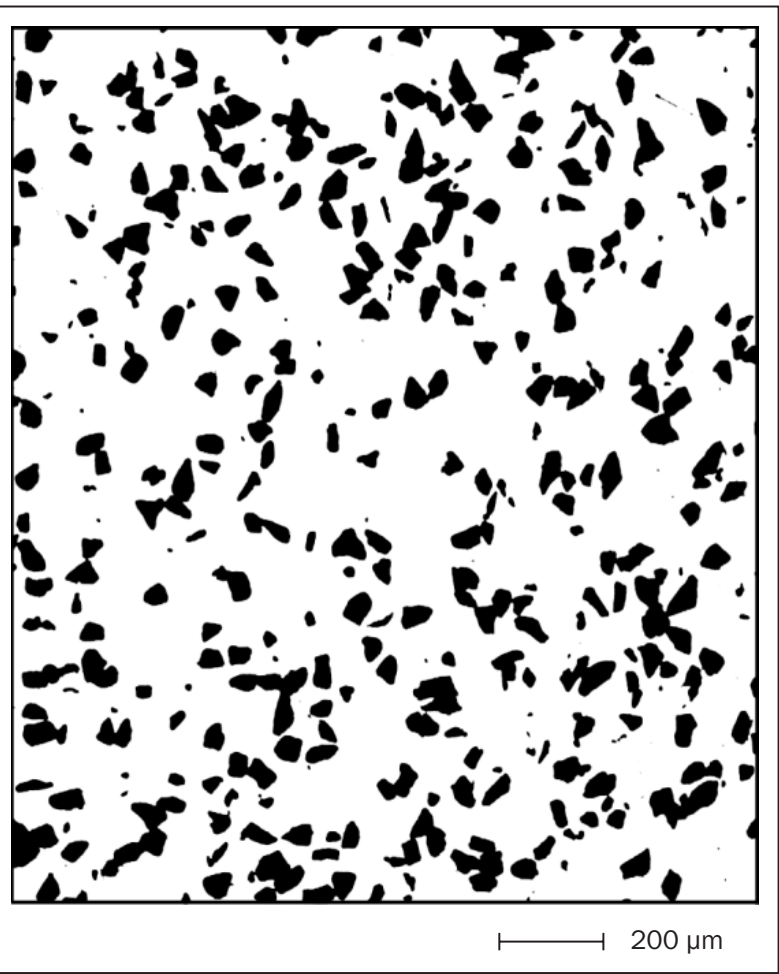

Figure 4 - $\mathrm{Al}+20 \mathrm{wt} \% \mathrm{Al}_{2} \mathrm{O}_{3}(50 \mu \mathrm{m})$

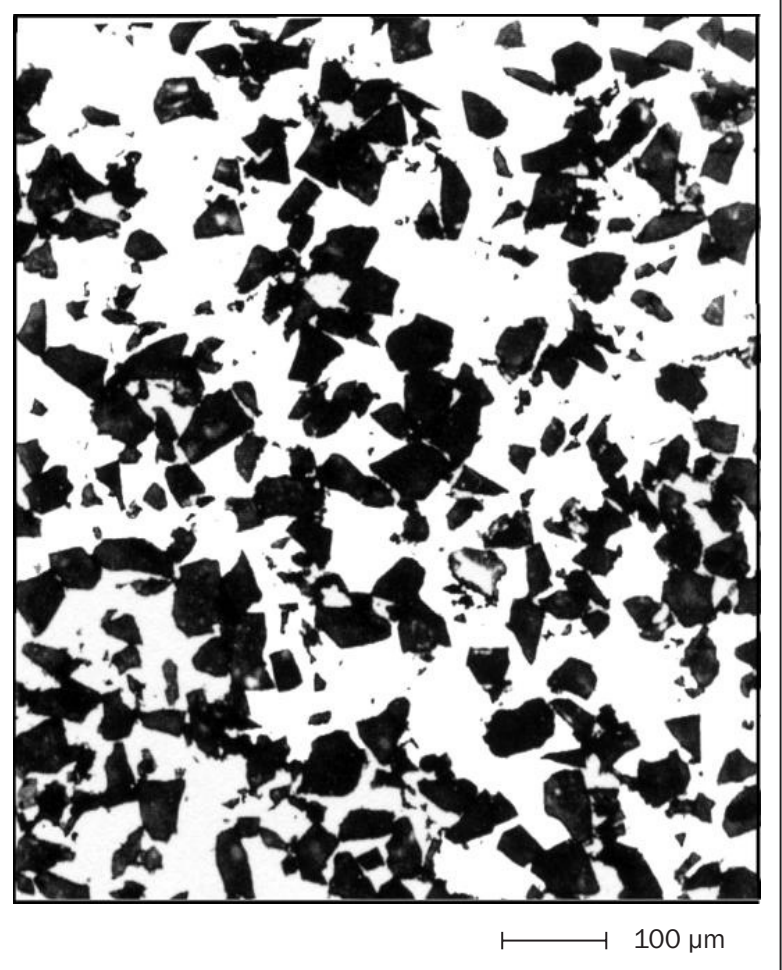

Figure 6 - $\mathrm{Al}+50 \mathrm{wt} \% \mathrm{Al}_{2} \mathrm{O}_{3}(50 \mu \mathrm{m})$

Figure 5 - $\mathrm{Al}+50 \mathrm{wt} \% \mathrm{Al}_{2} \mathrm{O}_{3}(22.5 \mu \mathrm{m})$

Figure 3-6: Optical micrographs of $\mathrm{Al} / \mathrm{Al}_{2} \mathrm{O}_{3}$ composites showing the $\mathrm{Al}_{2} \mathrm{O}_{3}$ particle distribution as a function of particle content and size

Also, smaller particles should provide higher strength than the larger ones. According to data from the literature [1] the form of the used hard phase-particle has high influence on the strength of composites. In case of equal content of particles, the needle-like, tubular and skin forms, if directed in one direction (nonisotropic), in comparison with the round ones, provide higher values of composite strength. Negative strength 
deviations are assigned first of all to poor binding of particles and matrix and non-homogeneous distribution of particles in the matrix.

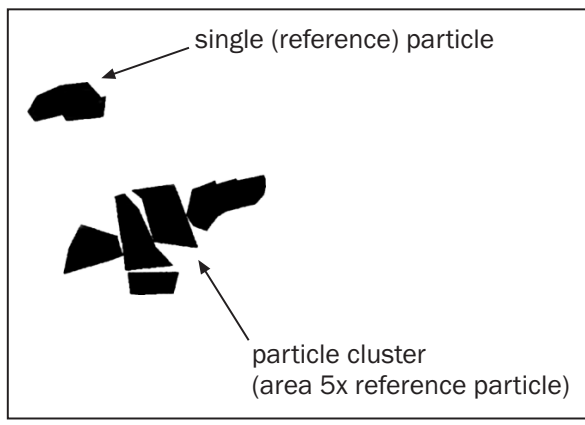

Figure 7 - Evaluation of the projected images for quantifying of particle clusters by image analysing computer
In the mentioned research the tensile strength shows increase with the increase in the content regardless of the size and type of $\mathrm{Al}_{2} \mathrm{O}_{3}$. Compared to the tensile strength of pure extruded aluminium $\mathrm{R}_{\mathrm{m}}=135 \mathrm{~N} / \mathrm{mm}^{2}, \mathrm{R}_{0,2}=95 \mathrm{~N} / \mathrm{mm}^{2}$, the composites show significantly higher values [1].

Smaller particles $22.5 \mu \mathrm{m}$ feature somewhat higher values than the rougher $50 \mu \mathrm{m}$ ones for both strength values $R_{m}$ and $R_{0,2}$. The fall in the strength of composites in case of the content of 50 mas.\% of rough particles is caused by strong clustering of particle agglomerates, where their possible direct contacts initiate fracture.

Positive strength deviations have been noted also in a greater number of studies of $\mathrm{Al}_{-} \mathrm{Al}_{2} \mathrm{O}_{3}$ composites [1]; however, due to the diversity of the used aluminium matrix-alloys and different processing methods, it is very difficult to compare the results. Mainly, the

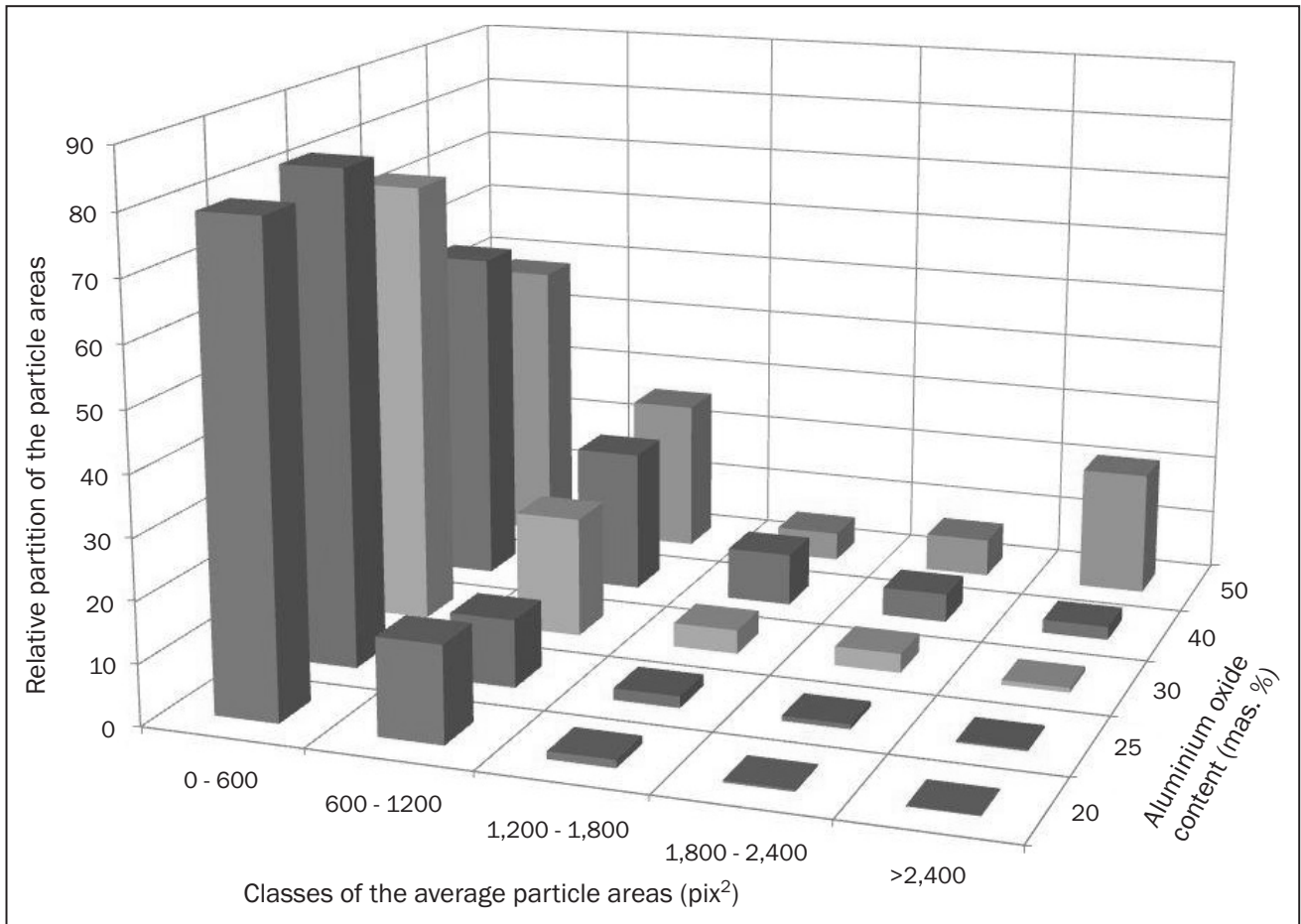

Figure 8 - Distribution of the average particle areas for different $\mathrm{Al}_{2} \mathrm{O}_{3}$ particle contents: Standard particle area was 100-600pix ${ }^{2}$

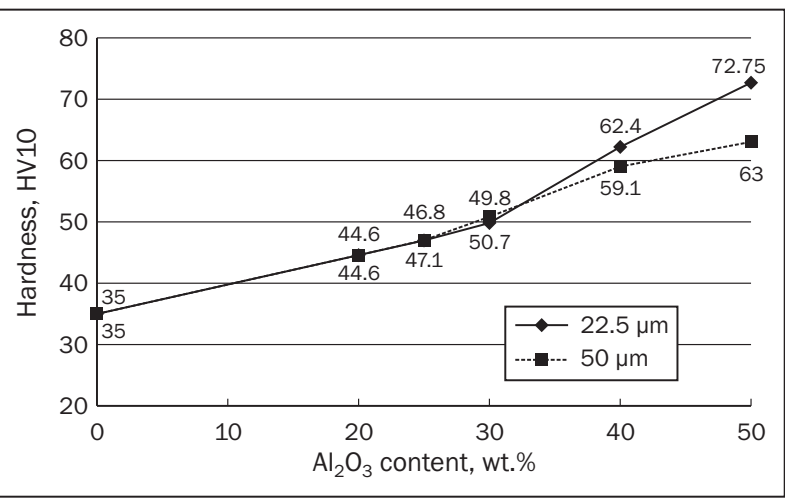

Figure 9 - Hardness of the $\mathrm{Al} / \mathrm{Al}_{2} \mathrm{O}_{3}$ composites as a function of the content and particle size of $\mathrm{Al}_{2} \mathrm{O}_{3}$ (Zesk)

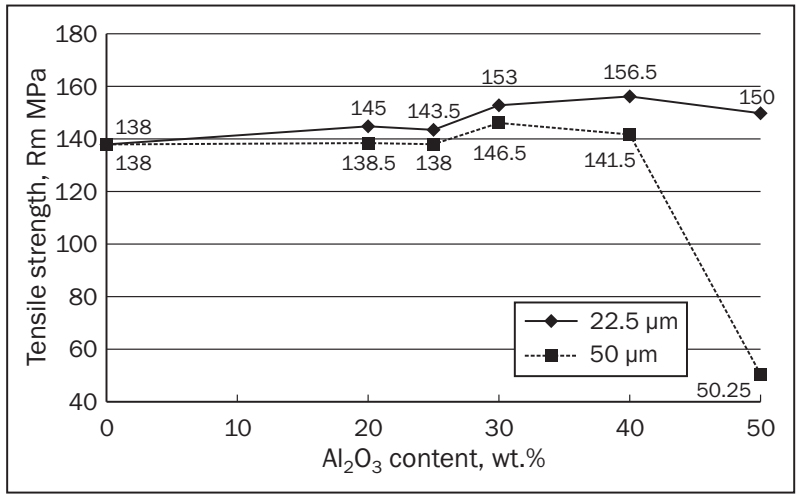

Figure 10 - Tensile strength of the $\mathrm{Al} / \mathrm{Al}_{2} \mathrm{O}_{3}$ composites as a function of the content and particle size of $\mathrm{Al}_{2} \mathrm{O}_{3}$ (Zesk) 


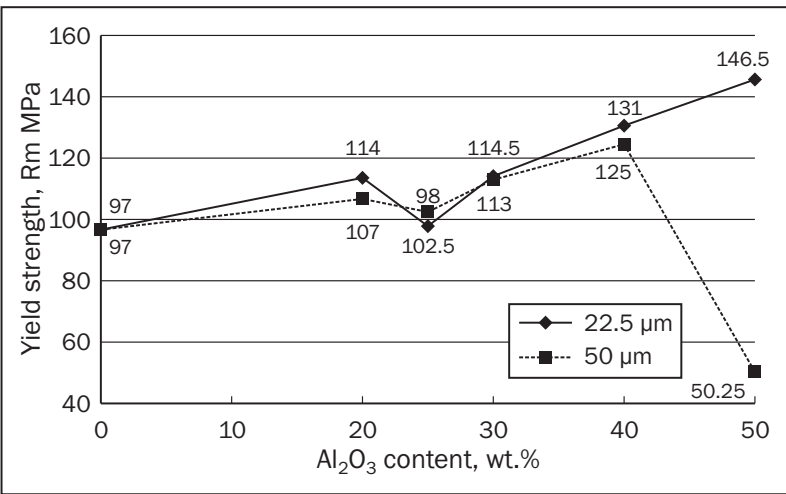

Figure 11 - Yield strength of the $\mathrm{Al} / \mathrm{Al}_{2} \mathrm{O}_{3}$ composites as a function of the content and particle size of $\mathrm{Al}_{2} \mathrm{O}_{3}$ (Zesk)

majority of research is based on $\mathrm{Al} / \mathrm{SiC}$ and $\mathrm{Al} / \mathrm{Al}_{2} \mathrm{O}_{3}$ composites with low content of hard phase. $\mathrm{Al} / \mathrm{Al}_{2} \mathrm{O}_{3}$ composites are mainly produced by casting, and as matrix metal, hard alloys of Al are used such as 6061, 2014 and 2024 among others [1, 8, 9, 10, 11]. Also, in these composites it is hard to compare the strength of composites with pure matrix due to the influence of particles on the precipitation processes. Furthermore, the nature of the very binding of the matrix and particle is completely different in cast composites than in those produced by powder metallurgy. In case of cast composites it is assumed that the bond between the particle and the matrix is realised by means of chemical reaction which results in the formation of $\mathrm{MgAl}_{2} \mathrm{O}_{4}$ or $\mathrm{CuAl}_{2} \mathrm{O}_{4}$ particles, on the interface 2014 or 2024$\mathrm{Al}_{2} \mathrm{O}_{3}$ of composite $[1,11]$.

In case of PM composites, due to low processing temperatures there are no chemical reactions so that bonding is purely mechanical. Also, the samples of pure Al powder, extruded, show somewhat higher values of strength than the cast ones. Since each single Al particle is covered by oxide film, this possibility of additional dispersion hardening of the composite during production is most likely. Furthermore, metallographic analyses and fracture analyses show that during pressing and extrusion the fracture of particles themselves has occurred to a minor extent.

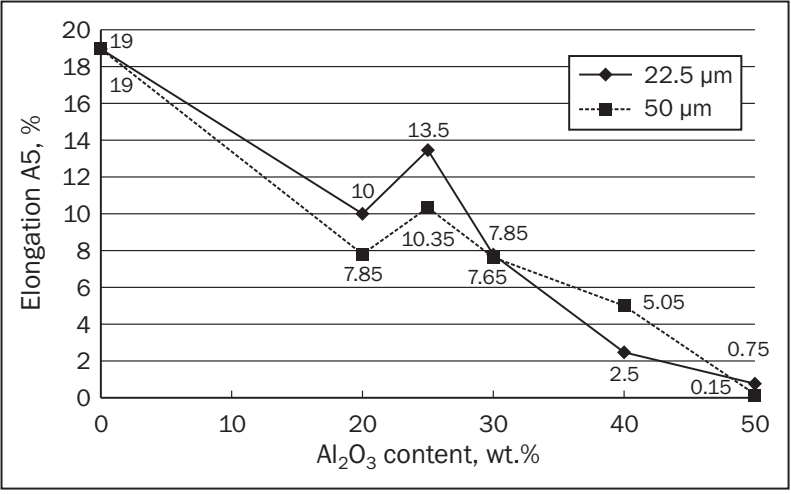

Figure 13 - Elongation of $\mathrm{Al} / \mathrm{Al}_{2} \mathrm{O}_{3}$ composites as a function of the content and particle size of $\mathrm{Al}_{2} \mathrm{O}_{3}$ (Zesk)

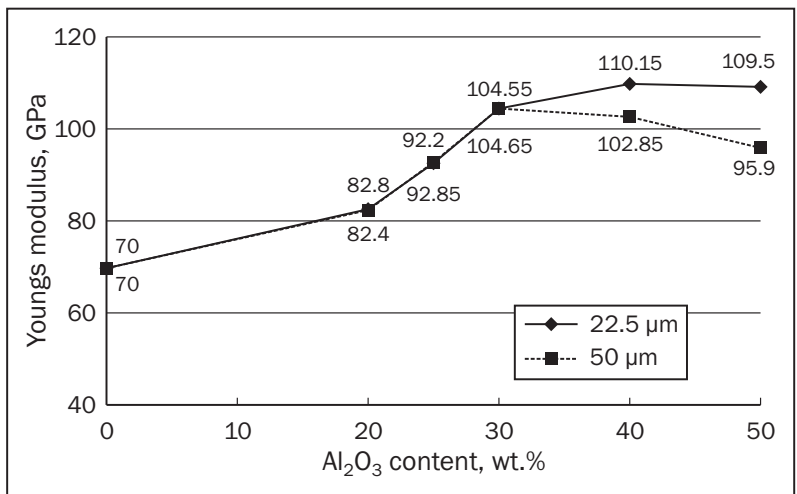

Figure 12 - Youngs modulus of $\mathrm{Al} / \mathrm{Al}_{2} \mathrm{O}_{3}$ composites as a function of the content and particle size of $\mathrm{Al}_{3} \mathrm{O}_{3}$ (Zesk)

The next contribution to the increase in the strength is possible due to the irregular shape of $\mathrm{Al}_{2} \mathrm{O}_{3}$ particles. Non-spherical particles orient themselves mildly in the direction of extrusion. Although processing temperatures are not high, the difference in the coefficient of constituent heat expansion is also one of the generators in causing dislocations.

Positive deviation is probably the sum of all the mentioned items, not neglecting either the hardening of the matrix-particle interface which occurred during material stress measurement precisely at the moment before fracture.

\subsection{Surface elongation and contraction}

In both cases, surface elongation and contraction decrease as the content of hard particles grows, which is expected since toughness is the property of the matrix. At lower content of finer $\mathrm{Al}_{2} \mathrm{O}_{3}(22.5 \mu \mathrm{m})$ particles, one can notice slightly higher values than those with rougher $\mathrm{Al}_{2} \mathrm{O}_{3}(50 \mu \mathrm{m})$ particles.

\subsection{Fracture}

Figures 15-18 show typical fracture surfaces. In case of lower $\mathrm{Al}_{2} \mathrm{O}_{3}$ content the particles delimited by

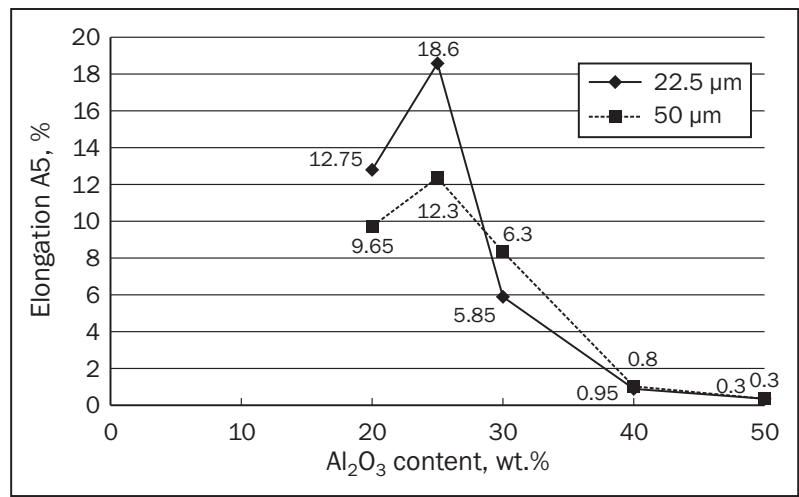

Figure 14 - Reduction of the area of $\mathrm{Al} / \mathrm{Al}_{2} \mathrm{O}_{3}$ composites as a function of the content and particle size of $\mathrm{Al}_{2} \mathrm{O}_{3}$ (Zesk) 
ductile matrix are visible and in smaller dimensions, fractured particles, indents as well as torn out particles. This suggests that the material fracture has been initiated at the places of decohesion of the particles

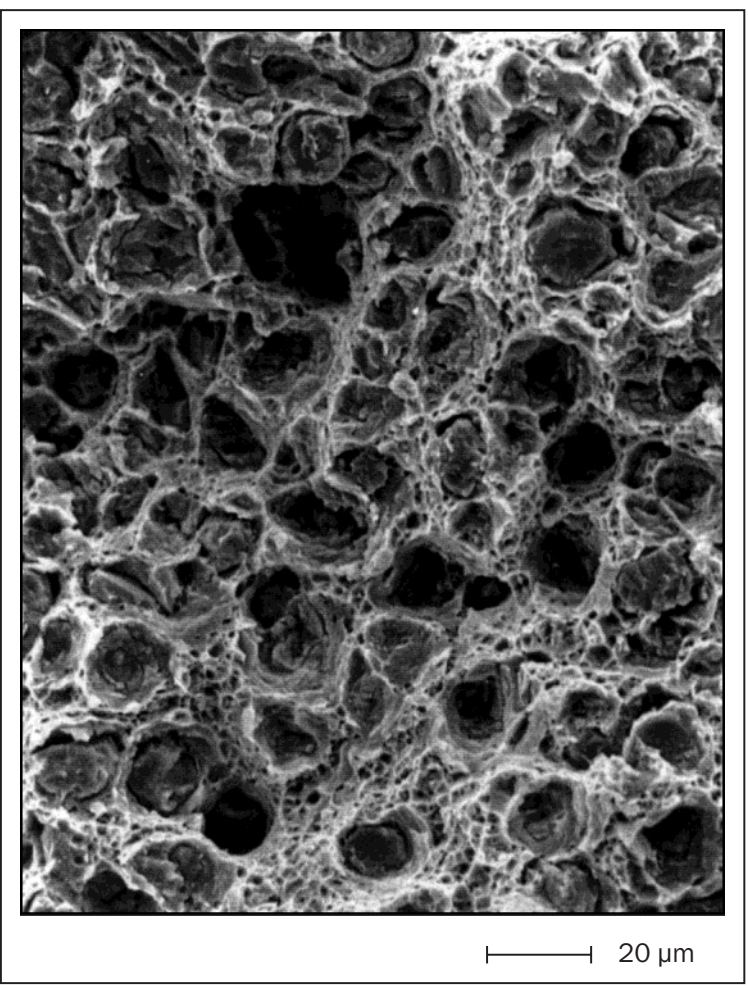

Figure $15-\mathrm{Al}+20 \mathrm{wt} \% \mathrm{Al}_{2} \mathrm{O}_{3}(22.5 \mu \mathrm{m})$

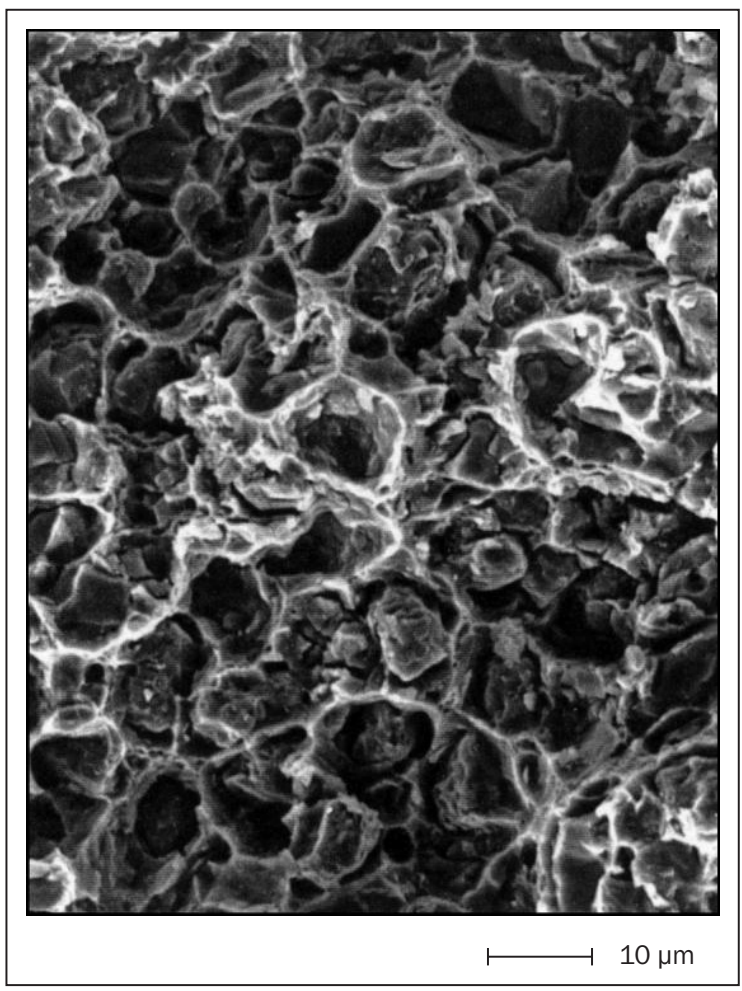

Figure $17-\mathrm{Al}+40 \mathrm{wt} \% \mathrm{Al}_{2} \mathrm{O}_{3}(22.5 \mu \mathrm{m})$ and the matrix. In case of higher content of $\mathrm{Al}_{2} \mathrm{O}_{3}$ the initial places of fracture are the particle agglomerates where there is possibility of direct contact of $\mathrm{Al}_{2} \mathrm{O}_{3}$ particles [12].

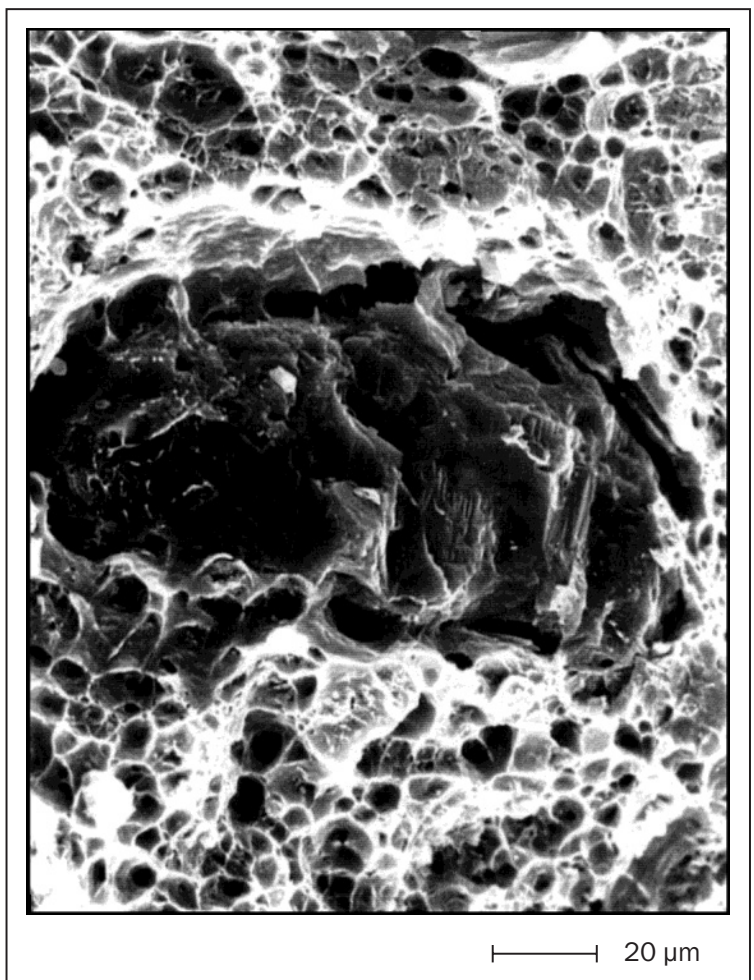

Figure 16 - $\mathrm{Al}+20 \mathrm{wt} \% \mathrm{Al}_{2} \mathrm{O}_{3}(50 \mu \mathrm{m})$

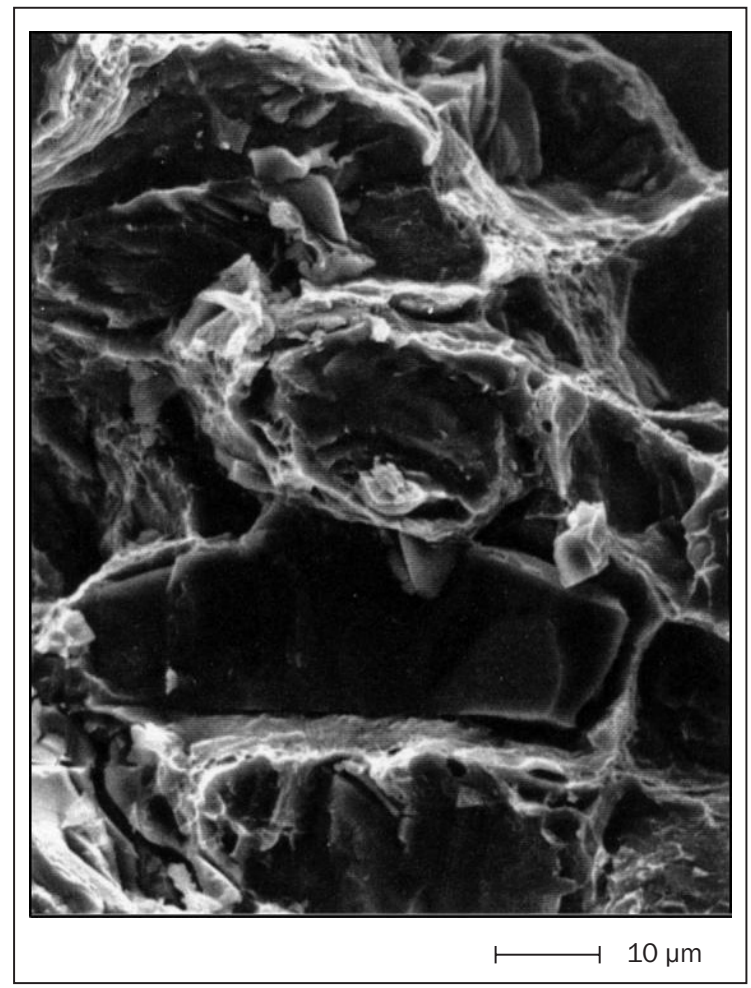

Figure $18-\mathrm{Al}+40 \mathrm{wt} \% \mathrm{Al}_{2} \mathrm{O}_{3}(50 \mu \mathrm{m})$

Figures 15-18: Scanning electron micrographs of the tensile fracture surface showing overall morphology, cracked and decohered $\mathrm{Al}_{2} \mathrm{O}_{3}$ particles, ductile tear ridges, pockets of shallow ridges and agglomeration of reinforcing particles 
K. Miloš, I. Jurić, P. Škorput: Aluminium-Based Composite Materials in Construction of Transport Means

Table 1 - Thermal expansion coefficient for $\mathrm{Al} / \mathrm{Al}_{2} \mathrm{O}_{3}$ composites depending on $\mathrm{Al}_{2} \mathrm{O}_{3}$ content

\begin{tabular}{||l|c|c|c|c|c||}
\hline \hline Content $\mathrm{Al}_{2} \mathrm{O}_{3}(50 \mu \mathrm{m})$ mas.\% & 0 & 20 & 30 & 40 & 50 \\
\hline Thermal expansion coefficient $\times 10^{-6} 1 / \mathrm{K}\left(50-450^{\circ} \mathrm{C}\right)$ & 26.25 & 23.25 & 21.63 & 19.65 & 19.30 \\
\hline
\end{tabular}

Table 2 - Mechanical properties of $\mathrm{Al}_{/} \mathrm{Al}_{2} \mathrm{O}_{3}$ (Zwsk) composites

\begin{tabular}{||c|c|c|c|c|c|c|c||}
\hline \multicolumn{2}{|c|}{$\mathrm{Al}_{2} \mathrm{O}_{3}$-Zwsk } & \multicolumn{6}{c||}{ Mechanical properties } \\
\hline Particle size & $\begin{array}{c}\text { Content } \\
\text { mas.\% }\end{array}$ & $\mathrm{HV}_{10}$ & $\begin{array}{c}\mathrm{R}_{0,2} \\
\mathrm{MPa}\end{array}$ & $\begin{array}{c}\mathrm{R}_{\mathrm{m}} \\
\mathrm{MPa}\end{array}$ & $\begin{array}{c}\mathrm{A}_{5} \\
\%\end{array}$ & $\begin{array}{c}\mathrm{Z} \\
\%\end{array}$ & $\begin{array}{c}\text { E-module } \\
\mathrm{GPa}\end{array}$ \\
\hline \hline $25 \mu \mathrm{m}$ & 20 & 46.2 & 109 & 142 & 11.8 & 17.8 & 82.2 \\
\hline $45 \mu \mathrm{m}$ & 20 & 45 & 111.5 & 141 & 9.6 & 13.6 & 82.8 \\
\hline \hline
\end{tabular}

Table 3 - Mechanical properties of $\mathrm{Al} / \mathrm{Al}_{2} \mathrm{O}_{3} /$ graphite composite

\begin{tabular}{||c|c|c|c|c|c|c||}
\hline \multicolumn{2}{|c|}{ Composite composition } & \multicolumn{5}{c||}{ Mechanical properties } \\
\hline $\mathrm{Al}_{2} \mathrm{O}_{3}, 22.5 \mu \mathrm{m}$, mas.\% & $\begin{array}{c}\text { Graphite, 75 } \mu \mathrm{m}, \\
\text { mas.\% }\end{array}$ & $\begin{array}{c}\mathrm{R}_{\mathrm{m}} \\
\mathrm{MPa}\end{array}$ & $\begin{array}{c}\mathrm{R}_{0,2} \\
\mathrm{MPa}\end{array}$ & $\begin{array}{c}\mathrm{A}_{5} \\
\%\end{array}$ & $\begin{array}{c}\mathrm{Z} \\
\%\end{array}$ & $\begin{array}{c}\text { E-module } \\
\mathrm{GPa}\end{array}$ \\
\hline \hline 25 & 2 & 130 & 105 & 5.7 & 6.9 & 90.2 \\
\hline 25 & 5 & 120 & 101.5 & 4.15 & 3.15 & 88.1 \\
\hline 0 & 15 & 107 & 91 & 4.65 & 5.6 & 71.4 \\
\hline 0 & 20 & 93 & 88 & 2.35 & 2.8 & 68.7 \\
\hline
\end{tabular}

\subsection{Thermal expansion coefficient}

The thermal expansion coefficient has been measured by dilatometry for the composites with rough $\mathrm{Al}_{2} \mathrm{O}_{3}$ particles for the temperature range from $50^{\circ} \mathrm{C}$ to $450^{\circ} \mathrm{C}$. The results show a fall in the coefficient with increase in $\mathrm{Al}_{2} \mathrm{O}_{3}$ content, which has been expected. Ceramic materials, due to their strong interatomic bonds have naturally lower coefficient of thermal expansion than metals. Measured at $20^{\circ} \mathrm{C}$, for $\mathrm{Al}_{2} \mathrm{O}_{3}$ of $99.5 \%$ purity it amounts to $7.2 \times 10^{-6} 1 / \mathrm{K}$, and for pure aluminium $23 \times 10^{-6} 1 / \mathrm{K}$. According to the theoretical model mixing rule, the composite material in ideal process conditions and ideal bonding of the matrix and hard phase should have the properties proportional to the shares of matrix and hard phase in composite [1][14].

\subsection{Influence of type $\mathrm{Al}_{2} \mathrm{O}_{3}$ on the mechanical properties of materials}

Comparing the results obtained for composites with $\mathrm{Al}_{2} \mathrm{O}_{3}$ (Zesk) and $\mathrm{Al}_{2} \mathrm{O}_{3}$ (Zwsk) particles, it is visible that there is no major difference.

\subsection{Influence of graphite on mechanical properties of $\mathrm{Al}_{2} \mathrm{O}_{3}$ composite materials}

$\mathrm{Al} / \mathrm{Al}_{2} \mathrm{O}_{3} /$ graphite composites regarding the obtained results have shown much worse properties than the composites with no graphite content. These results are the consequence of the worse bonding of graphite particles and matrices, as well as the matrices and the hard phase. Graphite particles have imposed themselves as independent intermediary layers.

\section{SIGNIFICANCE OF AL/AL $\mathrm{AO}_{3}$ COMPOSITE MATERIAL FOR THE CONSTRUCTION OF TRANSPORT MEANS AND THE TECHNOLOGY OF TRAFFIC AND TRANSPORT}

Based on the presented research results it may be seen that the integration of $\mathrm{Al}_{2} \mathrm{O}_{3}$ into pure aluminium by means of powder metallurgy techniques has resulted in the production of light and homogeneous composite material with satisfactory mechanical properties. Its further development, i.e. improvement of particle distribution through modification of their size and share as well as the process parameters, indicate great possibilities of application. Since this refers to ceramic particles, it is to be expected that, along with the excellent basis corrosion properties they will also feature satisfactory tribological behaviour of material.

In the construction of transport means this would mean the possibility of replacing iron, steel and their versions for the parts with the critical values of friction and wear of materials. For instance, today's average passenger car regarding mass contains about $65 \%$ of iron material. According to theoretical considerations, in case of the substitution of these materials by aluminium-based composites, having in mind the entire spectrum of materials, the mass would be reduced by $50-60 \%$ of the mentioned amount [14]. The fundamentally new production technologies brought by the 
composites open up new approaches to design and construction of the transport means as well as the possibilities of improvement of their individual parts. The improvement of the traffic and transport technology is primarily reflected in the reduction of the transport means mass which directly means saving in energy and efficiency of the transport means. Figure 1 shows the main domains of mass reduction reflections.

\section{CONCLUSION}

The purpose of this research has been the production of $\mathrm{Al} / \mathrm{Al}_{2} \mathrm{O}_{3}$ composite material with a content of up to 50 mas. $\% \mathrm{Al}_{2} \mathrm{O}_{3}$ by powder metallurgy techniques and the analysis of mechanical properties of the composite materials.

The results of the mentioned research indicate that $\mathrm{Al} / \mathrm{Al}_{2} \mathrm{O}_{3}$ composites with a content of up to 50 mas.\% $\mathrm{Al}_{2} \mathrm{O}_{3}$ can be produced by powder metallurgy techniques, i.e. by extrusion without any difficulties.

Good bonding of $\mathrm{Al}$ and $\mathrm{Al}_{2} \mathrm{O}_{3}$ has been achieved as well as the homogeneous distribution of the hard phase within the matrix of up to 30 mas. $\% \quad \mathrm{Al}_{2} \mathrm{O}_{3}$. Maximum impact on the mechanical properties is in the first place by the content and then by the size, whereas $\mathrm{Al}_{2} \mathrm{O}_{3}$ type has no major impact on the composite properties. Finer particles feature somewhat better properties than the rough ones. In higher contents of particles of 40 mas.\% and 50 mas.\%, the nonhomogeneous distribution of particles is seen in the form of particle cluster whose mutual contacts during stress initiate the propagation of cracks and then also in material fracture. This trend is more expressed in rougher particles. Regardless of the content, in all the tested samples a slight orientation of particles in the direction of extrusion has been noted. The addition of graphite both in the pure aluminium and in the composite has resulted in the deterioration of the mechanical properties.

As consequence of all this, future research should be directed to the processing of the tribological properties of materials.

\section{Dr. sc. KATICA MILOŠ}

E-mail: katica.milos@fpz.hr

Mr. sc. IVICA JURIĆ

E-mail: jurici@fpz.hr

Mr. sc. PERO ŠKORPUT

E-mail: pero.skorput@fpz.hr

Sveučilište u Zagrebu, Fakultet prometnih znanosti

Vukelićeva 4, 10000 Zagreb, Hrvatska

\section{SAŽETAK}

\section{KOMPOZITNI MATERIJALI NA BAZI ALUMINIJA U KONSTRUKCIJ PROMETNIH SREDSTAVA}

Primjena dostignuća materijalike kako u povijesti tako i danas izravno se očituje poboljšanjem efikasnosti prometnih sredstava što onda ima za posljedicu unaprjeđenje tehnologije prometa i transporta. Današnji zahtjevi u polju konstrukcijskih materijala namijenjenih izradi prometnih sredstava nalažu smanjenje mase kao jedan od temeljnih kriterija.

Razmatranja tehničko-tehnoloških društava usmjerena su na lake materijale i mogućnosti njihove modifikacije $u$ svrhu zamjene dosadašnjih tradicionalnih teških monolita poput željeza, čelika, bakra itd. Potencijal je prepoznat u aluminijski baziranim materijalima. Aluminij i njegove inačice već se uvelike rabe $u$ automobilskoj industriji, međutim njihov uporabni spektar još uvijek zaobilazi tribološki osjetljive namjene. Težište ovog rada je mogućnost izrade takvog materijala. U mekani aluminij integrirane su keramičke čestice $\mathrm{Al}_{2} \mathrm{O}_{3}$ različitih veličina čestica i udjela tehnikama metalurgije prašaka. Ispitivana su mehanička svojstva materijala u ovisnosti o udjelu, veličini čestice, tipu $\mathrm{Al} / \mathrm{Al}_{2} \mathrm{O}_{3}$, kao i dodatku grafita. $\mathrm{Al} / \mathrm{Al}_{2} \mathrm{O}_{3}$ kompoziti su proizvedeni bez poteškoća i pokazali su zadovoljavajuća mehanička svojstva.

\section{KLUČNE RIJEČI}

smanjenje mase prometnih sredstava, kompoziti na bazi aluminija, $\mathrm{Al} / \mathrm{Al}_{2} \mathrm{O}_{3}$ kompoziti,

\section{LITERATURE}

[1] Miloš, K.: Dissertation: Pulvermetallurgisch Hergestellte Al-Werkstoffe mit Al203-Teichenverstaerkung, Technische Universitaet Wien, 1994.,Wien

[2] Asnafi, N., Nilsson, T., Lassl, G.: Tubular hydroforming of automotive side members with extruded aluminium profiles, Journal of Materials Processing Technology 142 (2003) 93-101

[3] Chen, C., Ren, Y.: Exploring the relationship between vehicle safety and fuel efficiency in automotive design, Transportation Research Part D 15(2010) 112-116

[4] Hutchinson, T.P., Anderson, R.W.G.: Vehicle mass as a determinant of fuel consumption and secondary safety performance: A comment, Transportation Research Part D 15(2010) 123-125

[5] Kok, M.: Production and mechanical properties of particle reinforced 2024 aluminium alloy composites, Journal of Materials Processing Technology 161 (2005) 381-387 
[6] Kouzeli, M., Mortensen, A.: Size dependent strengthening in particle reinforced aluminium, Acta Materialia 50(2002)39-51

[7] Barlow, I.C., Jones, H., Rainforth, W.M.: Coarsening kinetics at $600^{\circ} \mathrm{C}$ of $\mathrm{Al} 203$ dispersoids in a mechanically alloyed aluminium alloy, Scripta Materialia 47 (2002) 331-335

[8] Dobrazanski, L.A., Wlodarczyk, A., Adamiak, M.: The structure and properties of PM composite materials on AW-2124 aluminium alloy reinforced with the $B N$ or Al203 ceramic particles, Journals of Materials Processing Technology 175(2006) 186-191

[9] Chou, S.N., Lu, H.H., Lii, D.F., Huang, J.L.: Processing and physical properties of Al203/aluminium alloy composites, Ceramics International 35(2009)7-12

[10] Kouzeli, M., Weber, L., San Marchi, C., Mortensen, A.: Influence of damage on tensile behavior of pure aluminium reinforced with $\geq 40 \mathrm{vol} \%$ alumina particles, Acta.mater.49 (2001) 3699-3709

[11] Vaucher, S., Beffort-EMPA Thun, O.: Bonding and Interface Formation in Metal Matrix Composites, Thematic Network, Vol. 9, MMC Assess Consortium, September 2001

[12] Srivatsan, T.S., Al-Hajri, M., Smith, C., Petraroli, M.: The tensile response and fracture behavior of 2009 aluminium alloy metal matrix composite, Materials Science and Engineering A346(2003) 91-100
[13] German, R.M.: Powder Metallurgy Science, MPIF, Princeton 1984

[14] Miloš, K., Miloš, I., Ćurepić, D.: Composite Materials in the Construction of Transportation Means, PrometTraffic-Trafico, Vol. 16, 2004, No. 1, 37-46

[15] Carlson, B.T.: Selecting material for the exterior panel of a private car backdoor by adopting a total cost accounting approach, Materials and Design, 30 (2009) 826-832

[16] Miller, W.S., Zhuang, L., Bottema, J., Witterbrood, A.J., De Smet, P., Haszler, A., Vierage, A.: Recent development in aluminium alloys for the automotive industry, Materials Science and Engineering A280 (2000)37-49

[17] Stodolsky, F., Vyas, A., Cuenca, R., Gaines, L.: Life-Cycle Energy Savings Potential from Aluminium-Intensive Vehicles, 1995 Total Life Cycle Conference and Exposition, October 16'19, 1995, Vienna, Austria

[18] Kleiner, M., Geiger, M., Klaus, A.: Manufacturing of Lightweight Components by Metal Forming, CIRP Annals-Manufacturing Technology, Vol. 52, (2003) 521542

[19] Patricia PAAH Kandelaars, Jan D.van Dam: An analysis of variables influencing the material composition of automobiles, Resources, Conservation and Recycling 24 (1998) 323-333 